Provided for non-commercial research and education use. Not for reproduction, distribution or commercial use.

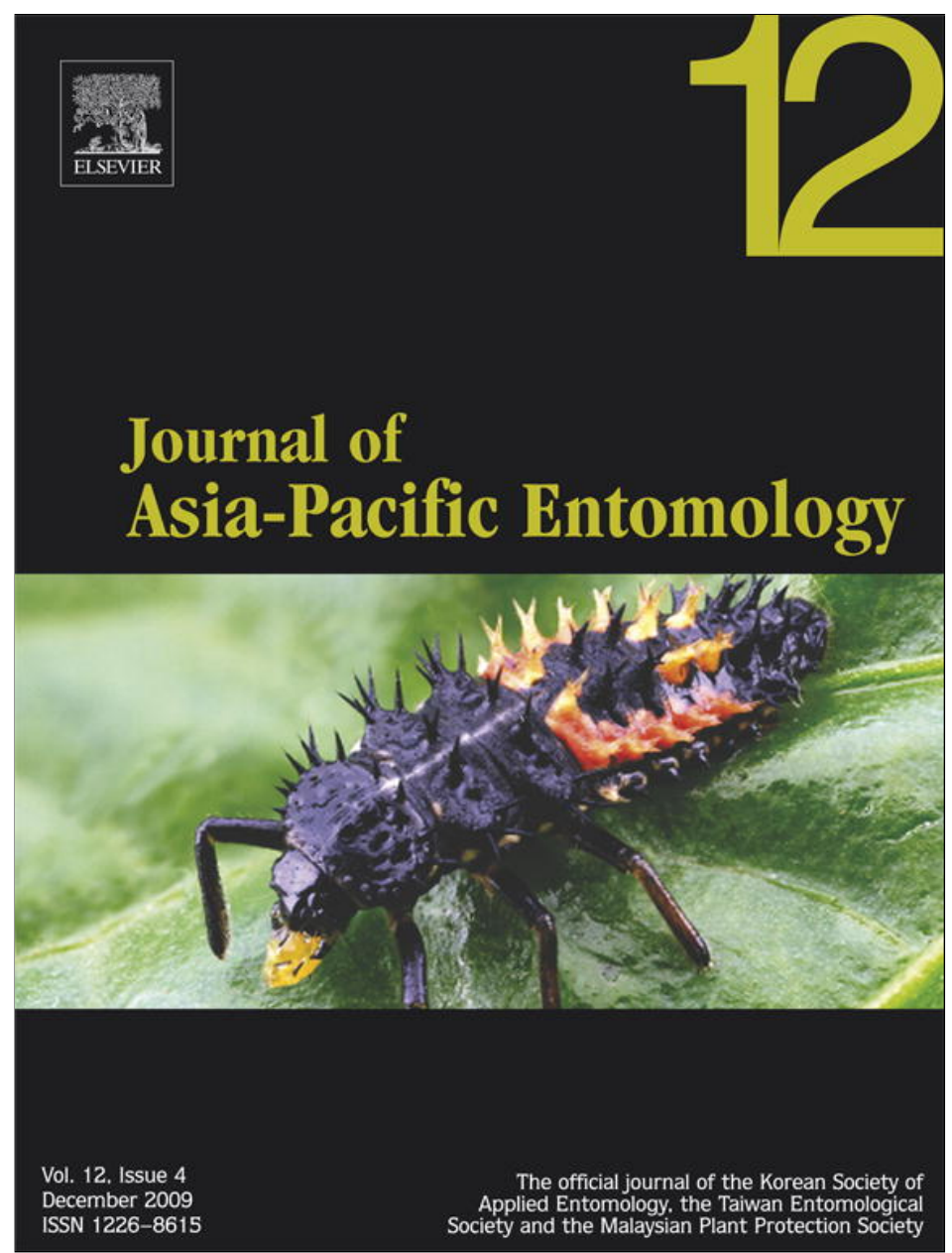

This article appeared in a journal published by Elsevier. The attached copy is furnished to the author for internal non-commercial research and education use, including for instruction at the authors institution and sharing with colleagues.

Other uses, including reproduction and distribution, or selling or licensing copies, or posting to personal, institutional or third party websites are prohibited.

In most cases authors are permitted to post their version of the article (e.g. in Word or Tex form) to their personal website or institutional repository. Authors requiring further information regarding Elsevier's archiving and manuscript policies are encouraged to visit:

http://www.elsevier.com/copyright 


\title{
Treatment of millet crop plant (Sorghum bicolor) with the entomopathogenic fungus (Beauveria bassiana) to combat infestation by the stem borer, Chilo partellus Swinhoe (Lepidoptera: Pyralidae)
}

\author{
Narasimha P. Reddy ${ }^{a}$, Akbar P. Ali Khan ${ }^{\text {a }}$, Uma K. Devi ${ }^{a}{ }^{\text {,* }}$, Hari C. Sharma ${ }^{\text {b }}$, Annette Reineke ${ }^{c}$ \\ a Department of Botany, Andhra University, Visakhapatnam, 530 003, AP, India \\ b Entomology Division, ICRISAT, Patancheru, 502 324, AP, India \\ c Geisenheim Research Institute, Section of Phytomedicine, Von-Lade-Str. 1, D-65366 Geisenheim, Germany
}

\section{A R T I C L E I N F O}

\section{Article history:}

Received 21 January 2009

Revised 4 June 2009

Accepted 9 June 2009

\section{Keywords:}

Sorghum

Entomopathogenic fungus

Beauveria bassiana

Endophytism

Chilo partellus

Reduction in stem tunneling

\begin{abstract}
A B S T R A C T
Experiments were done to test if Beauveria bassiana can become an endophyte in sorghum and confer protection from stem borer. Four-week-old sorghum seedlings were treated with $B$. bassiana. The plants were examined for endophytic presence of $B$. bassiana, 30 and 60 days after treatment. Stem cultures from treated plants showed growth of $B$. bassiana. PCR amplification using fungal specific primers for a conserved region of $\beta$ tubulin gene yielded identical 360 bp products from both $B$. bassiana and treated sorghum plants. In a subsequent experiment, $B$. bassiana treated and untreated (control) sorghum plants were artificially infested with stem borer (Chilo partellus) larvae 15 days post treatment and the extent of damage was compared. About $40 \%$ of the control plants developed dead heart while no plant in the B. bassiana treated plot did. In the surviving control plants, stem tunneling by shoot borer was significantly higher compared to $B$. bassiana treated sorghum plants.
\end{abstract}

(c) Korean Society of Applied Entomology, Taiwan Entomological Society and Malaysian Plant Protection Society, 2009 Published by Elsevier B.V. All rights reserved.

\section{Introduction}

Sorghum bicolor (L.) Moench is a drought tolerant, nutrient rich millet crop. It is extensively cultivated in poor soils in rainfed fields of the semi-arid tropics of India and Africa and it is used both for grain and cattle fodder. Of the several insect pests infesting this crop, the stem borer, Chilo partellus Swinhoe (Lepidoptera: Pyralidae), is among the most severe ones, causing an 18-53\% yield loss (Gethi et al., 2001). Stem borer resistant sorghum varieties are not available. Chemical methods used to manage stem borer are not only ineffective but also not affordable to the resource poor dry land farmer.

Beauveria bassiana (Bals.) Vuillemin, an entomopathogenic fungus with no known phytopathogenic activity, establishes endophytically in corn and confers protection from the stem borer, Ostrinia nubilalis (Wagner and Lewis, 2000; Arnold and Lewis, 2005). B. bassiana also establishes endophytically in potatoes, jimsonweed, cotton and cocklebur (Jones, 1994), tomatoes (Leckie, 2002), opium poppy (Quesada-Moraga et al., 2006), the bark of Carpinus carolinata (Bills and Polishook, 1991), Theobroma cacao (Posada and Vega, 2005), date palm (Gomez et al., 2006), coffee (Posada and Vega, 2006; Posada et al., 2007) and banana (Akello et al., 2008).

\footnotetext{
* Corresponding author. Fax: +91 8912755547.

E-mail address: umadevikoduru@gmail.com (U.K. Devi).
}

B. bassiana was pathogenic to sorghum stem borer in laboratory bioassays and in field treatments (Maniania, 1993; Uma Devi et al., 2001). We determined if the establishment of $B$. bassiana as an endophyte in sorghum can be facilitated through artificial inoculation and if it provides protection from the stem borer.

\section{Materials and methods}

B. bassiana isolate ITCC 4688 (Indian type culture collection, IARI, Delhi, India) that caused $\sim 80 \%$ mortality of the larvae of $C$. partellus in laboratory bioassays (Uma Devi et al., 2001) was selected for the experiment. It was mass cultured on rice as described by Jenkins et al. (1998). The conidiated rice culture was used directly in some treatments. For spray applications, the conidia on the rice culture were harvested (through sieving) to make an aqueous conidial suspension. A sorghum variety, 'Annapurna', which is extensively cultivated in south India and susceptible to shoot borer, was treated. Second generation larval populations of laboratory bred C. partellus established from field collected insects were used in the experiments.

The experiments were conducted twice during Rabi season (January-April) in 2005 and 2006. Temperatures ranged from 27 to $32{ }^{\circ} \mathrm{C}$ (day) and 20 to $26{ }^{\circ} \mathrm{C}$ (night). In the first time experiment, sorghum plants were treated with $B$. bassiana to test if the fungus was established in the plant. When it was ascertained that the fungus was established in the plant with no unfavourable effect on growth or 
yield, the experiment was done the second time with artificial infestation of sorghum plants with $C$. partellus larvae post treatment with $B$. bassiana, to test if the endophytic $B$. bassiana deterred damage of the plant by the borer.

\section{Experimental design}

For experiments in the first season, a single plot with three replicates for each treatment with different treatments arranged as split plots was designed (Lewis et al., 2001). Each replicate treatment block consisted of 100 plants, for a total of 300 plants per treatment. To prevent cross contamination by B. bassiana conidia due to wind, control plants (not treated with B. bassiana) were grown $200 \mathrm{~m}$ away from the treated plot with a rice plot in between. Plants were grown in rows with spacing of $0.5 \mathrm{~m}$ between rows and $1 \mathrm{~m}$ between plants. Usual agronomic practices, including fertilizer application and manual weeding, were done both in the treated and control plots. The field was irrigated prior to B. bassiana treatment. This was to maintain high humidity (favourable for fungal establishment) in the microenvironment of the plots. $B$. bassiana treatment was done in the evening when temperatures were considerably lower $\left(25-28{ }^{\circ} \mathrm{C}\right)$ than day temperatures.

\section{Treatment with B. bassiana}

Four-week-old sorghum seedlings were treated with $B$. bassiana. The mean height (base of the stem to the point of whorl) of the plants at this stage was approx. $18 \mathrm{~cm}$. The plants were treated with either conidiated culture on rice or with an aqueous conidial spray.

Treatment with conidiated fungal culture on rice substrate

A 14-day-old conidiated culture of $B$. bassiana on rice $\left(10^{12}\right.$ conidia $\mathrm{g}^{-1}$ ) was placed in the leaf whorl ( $5 \mathrm{~g} /$ plant). The control plants were treated with rice $(5 \mathrm{~g} /$ plant) processed as for mass culture of $B$. bassiana but with no fungus.

\section{Treatment with aqueous conidial spray}

Each plant was sprayed with approx. $10 \mathrm{ml}$ of an aqueous conidial suspension $\left(5 \times 10^{9}\right.$ conidia $\left.\mathrm{ml}^{-1}\right)$ with $1 \%$ Tinopal LPW (Sigma Chemical Co., St. Louis, USA), a stilbene-derived optical brightener and $0.01 \%$ Tween 80 . The controls were treated with an equal volume of water with $1 \%$ Tinopal LPW and $0.01 \%$ Tween 80 . Tinopal was used to protect conidia from damage caused by UV rays in sunlight (Inglis et al., 1995). Tween was used to disperse the conidia and act as a surfactant.

\section{Evaluation for endophytic presence of B. bassiana in sorghum}

The endophytic establishment of $B$. bassiana in sorghum was tested through stem culture and by PCR reaction. For stem culture, B. bassiana treated sorghum stems were inoculated on Sabouraud dextrose yeast agar (SDAY) medium (Bing and Lewis, 1991). PCR reaction was set up with primers specific for fungal $\beta$ tubulin gene with DNA of $B$. bassiana treated sorghum plants.

To set up stem cultures, 10 plants were randomly selected 30 and 60 days after treatment from each replicate block in the treatment and control. The plants were uprooted and the covering of leaf bases was peeled off to obtain the stem. Three- $1 \mathrm{~cm}$ pieces were cut at different heights of the stem (Table 1). For PCR, two plants from each replicate block were selected at random for DNA extraction.

\section{Stem culture}

SDAY medium was prepared with $0.01 \%$ Chloramphenicol $\left(0.05 \mathrm{mg} \mathrm{ml}^{-1}\right)$ and Streptomycin $\left(0.05 \mathrm{mg} \mathrm{ml}^{-1}\right)$ (to prevent bacterial contamination) and $0.1 \%$ crystal violet (to provide contrast for visualizing fungal growth (Chase et al., 1986)). The stem pieces were surface-sterilized first with $96 \%$ ethanol for $1 \mathrm{~min}$, then with $6 \%$ sodium hypochlorite $(\mathrm{NaOCl})$ solution for $5 \mathrm{~min}$, followed by $96 \%$ ethanol for $30 \mathrm{~s}$ (Luginbuhl and Muller, 1980). To ascertain the efficiency of the surface-sterilization method, surface-sterilized stem pieces were imprinted onto SDAY plates. The absence of fungal or bacterial growth on these slants indicated the fidelity of the applied sterilization technique (Ganley and Newcombe, 2006). To set up cultures, each stem piece was cut longitudinally with a sterile scalpel and plated on SDAY medium (4 pieces/culture slant) with the pith side touching the medium. The culture slants with inoculated stem pieces were incubated in an environmental chamber set at $25 \pm 1{ }^{\circ} \mathrm{C}$ and $90 \%$ RH with no light. They were examined daily for up to 15 days. When fungal growth and conidia appeared, the conidia were mounted on a slide and examined under a microscope. If the conidial morphology resembled B. bassiana, the fungus was inoculated in a new culture slant with SDAY medium with antibiotics to obtain a pure culture. The number of plants that showed endophytic presence of $B$. bassiana among the total tested was computed as \% value.

PCR amplification using primers specific for fungal $\beta$ tubulin gene

DNA was extracted from $B$. bassiana treated sorghum, untreated sorghum (negative control) and B. bassiana isolate ITCC 4688 used in treating sorghum (positive control), as described in Uma Devi et al. (2006). Primers for a conserved region of fungal $\beta$ tubulin gene (360 bp) (Bt2a-fwd: 5'-GTAACCAAATCGGTGCTGCTTTC-3' and Bt2brev: 5'-ACCCTCAGTGTAGTGACCCTTGGC-3') (Glass and Donaldson, 1995) were used. PCR reaction was set up in a total volume of $25 \mu \mathrm{l}$. The reaction mixture consisted of $1 \mu \mathrm{l}$ of DNA (50 ng/ $\mu \mathrm{l}), 2.5 \mu \mathrm{l}$ of $10 \times$ PCR buffer with $15 \mathrm{mM} \mathrm{MgCl}, 0.3 \mu \mathrm{l} 5 \mathrm{U}$ Taq polymerase, $2.5 \mu \mathrm{l}$ $2 \mathrm{mM}$ dNTPs (Metabion, Martinsried, Germany), and $1 \mu \mathrm{l}(20 \mathrm{pM})$ each of the forward and reverse primers and made up to a final volume of $25 \mu \mathrm{l}$ with sterile double distilled water. PCR reaction was carried out in a Mastercycler ${ }^{\circledR}$ ep Eppendorf thermocycler (Eppendorf, Hamburg, Germany). The PCR programme was set as follows: an initial cycle of $94{ }^{\circ} \mathrm{C}$ for $3 \mathrm{~min}$, followed by 30 cycles at $94{ }^{\circ} \mathrm{C}$ for $30 \mathrm{~s}$,

Table 1

Endophytic colonization of the entomopathogenic fungus Beauveria bassiana in sorghum stems.

\begin{tabular}{|c|c|c|c|c|c|c|c|}
\hline \multirow[t]{4}{*}{ Treatment method } & \multicolumn{6}{|c|}{ \% Endophytic colonization ${ }^{\mathrm{a}}$} & \multirow{4}{*}{$\begin{array}{l}\text { ANOVA (between } \\
\text { different collection } \\
\text { times) }\end{array}$} \\
\hline & \multicolumn{3}{|c|}{ 30th day post treatment } & \multicolumn{3}{|c|}{ 60th day post treatment } & \\
\hline & \multicolumn{3}{|c|}{ Height of the stem from the base } & \multicolumn{3}{|c|}{ Height of the stem from the base } & \\
\hline & $3 \mathrm{~cm}$ & $18 \mathrm{~cm}$ & $33 \mathrm{~cm}$ & $5 \mathrm{~cm}$ & $25 \mathrm{~cm}$ & $45 \mathrm{~cm}$ & \\
\hline \multirow{2}{*}{$\begin{array}{l}\text { Aqueous conidial (B. bassiana) } \\
\text { spray ANOVA (between different heights) } \\
\text { Conidiated B. bassiana culture on } \\
\text { rice ANOVA (between different heights) }\end{array}$} & \multicolumn{3}{|c|}{$F_{2,4}=182.23, P<0.05$} & \multicolumn{3}{|c|}{$F_{2,4}=64.23, P<0.05$} & \multirow{3}{*}{$\begin{array}{l}F_{5,10}=33.54 \\
P<0.05 \\
F_{5,10}=51.44 \\
P<0.05\end{array}$} \\
\hline & \multicolumn{3}{|c|}{$F_{2,4}=44.26, P<0.05$} & \multicolumn{2}{|c|}{$F_{2,4}=27.88, P<0.05$} & $64.17 \pm 0.49$ & \\
\hline ANOVA (between treatments) & $\begin{array}{l}F_{1,2}=10.33 \\
P<0.05\end{array}$ & $\begin{array}{l}F_{1,2}=43.35, \\
P<0.05\end{array}$ & $\begin{array}{l}F_{1,2}=163.18 \\
P<0.05\end{array}$ & $\begin{array}{l}F_{1,2}=25.66, \\
P<0.05\end{array}$ & $\begin{array}{l}F_{1,2}=26.63, \\
P<0.05\end{array}$ & $\begin{array}{l}F_{1,2}=34.91 \\
P<0.05\end{array}$ & \\
\hline
\end{tabular}

Values represent mean \pm SE of 20 plants from each of the three replicates.

a Values are angular transformed (arc sine $\sqrt{ }$ percentage) before analysis, back-transformed and rounded. 
$55^{\circ} \mathrm{C}$ for $1 \mathrm{~min}$ and $72{ }^{\circ} \mathrm{C}$ for $30 \mathrm{~s}$, followed by a final extension at $72{ }^{\circ} \mathrm{C}$ for 2 min.

Following PCR amplification, an aliquot $(5 \mu \mathrm{l})$ of PCR reaction mixture from each sample was electrophoresed on a $1 \%$ agarose gel with SYBR safe dye (Invitrogen, Germany). The gel was viewed on a transilluminator to identify samples with amplification products. The PCR amplified product of one sample each from DNA of $B$. bassiana treated sorghum plants as well as from pure B. bassiana fungal culture was sequenced. For sequencing, the DNA of the amplified product was retrieved as follows: the PCR reaction mixture was run on a $1 \%$ agarose gel, the respective amplification product was visualized on a dark reader (Clare Chemical Research, Colorado, USA) and cut out. The DNA in the gel piece was purified using Perfectprep ${ }^{\circledR}$ gel cleanup kit (Eppendorf, Hamburg, Germany) following the instructions of the manufacturer and DNA concentration was estimated spectrophotometrically. PCR products were sequenced in both directions on an automated Applied Biosystems 3730/xl/96-capillary DNA Analyzer (PE Applied Biosystems Inc., Weiterstadt, Germany) using the same primers as used for the initial PCR reactions and the BigDye ${ }^{\circledR}$ Terminator v3.1 Cycle sequencing kit (PE Applied Biosystems Inc., Weiterstadt, Germany). The sequences were compared to the entries in GenBank database using BLASTn programme (Altschul et al., 1990) to identify homologous sequences. Obtained sequences were deposited in GenBank.

Comparison of similarity between B. bassiana used for treatment of sorghum plants (ITCC 4688) and B. bassiana retrieved from sorghum stem cultures through AFLP fingerprinting

B. bassiana occurs naturally as an endophyte in corn (Bing and Lewis, 1991). To check if the B. bassiana retrieved from stem cultures of sorghum is a natural inhabitant, or the artificially inoculated strain, a DNA fingerprinting technique (amplified fragment length polymorphism, AFLP) was applied. The AFLP fingerprints of the $B$. bassiana isolate ITCC 4688 used for treating sorghum and three fungal cultures retrieved from $B$. bassiana treated sorghum stem cultures and PCR checked for the amplification of $\beta$ tubulin sequence, were generated as described in Uma Devi et al. (2006). Three primer sets were used - Pst-A/Mse-CAT, Pst-C/Mse-CAT and Pst-C/Mse-CTA.

\section{Assessment of growth and yield in B. bassiana treated sorghum}

The growth (plant height) and yield (grain weight) of B. bassiana treated and control sorghum plants were compared to determine if B. bassiana had an adverse effect on the plants. The plant height was measured 30 days and 60 days after treatment. Twenty plants from each replicate were measured. The height was measured on the 30th day after treatment from the base of the stem to the tip of the top most leaf on the main tiller. On the 60th day, the height was measured from the base of the stem to the tip of the panicle on the main tiller. To assess yield, mature panicles from 20 plants from each treatment block were collected. The grain was threshed and its weight was determined.

B. bassiana treated sorghum plants showed brown spots on leaves. Myrothecium roridum causes brown leaf spot disease in millets. Microscopic observations of leaves with the brown spot conformed to the descriptions of $M$. roridum spores. The control plants (not treated with $B$. bassiana) did not show brown spot symptoms.

\section{Artificial infestation of sorghum with stem borer larvae}

For another experiment, six $25 \mathrm{~m} \times 25 \mathrm{~m}$ ( $0.25 \mathrm{ha})$ plots $100 \mathrm{~m}$ apart, each with three replicate blocks (with 100 plants each), were designed. Each plot was assigned to a different treatment: 1 and 2) aqueous conidial spray/conidiating fungal culture of $B$. bassiana treatments followed by artificial infestation with $C$. partellus larvae, 3 ) untreated sorghum artificially infested with stem borer larvae, 4 and 5) two types of B. bassiana treatment and 6) sorghum not treated with $B$. bassiana (Table 3 ). The between row and plant spacing as well as the treatment of sorghum plants with $B$. bassiana was similar to the experiments described above. At the time of treatment with $B$. bassiana, the sorghum plants showed a mild infestation (natural) of aphids. Fifteen days after treatment with B. bassiana, the plants were artificially infested with stem borer. First instar larvae of the stem borer were carefully placed with a camel hair brush in the stem whorl (Lewis et al., 2001). Thirty larvae were placed per plant. Twenty days after artificial infestation with larvae, 20 plants from each treatment block were randomly selected to check if larvae were successful in colonizing the plants. The number of larvae in the leaf whorl and within the stem (examined by splitting open the stem) of each plant was noted. When the plants were 12 weeks old and the panicles were at hard dough stage, 20 plants in each treatment block were uprooted. They were split longitudinally from the panicle to the base of the plant, and the extent of tunneling caused by stem borer was measured by summing up the length of all the tunnels within the stem. The number of plants with dead hearts and those which did not bear panicles was counted in each block. The plant height and grain yield were measured as described in the first time experiment. The endophytic establishment of B. bassiana was checked through PCR of 2 randomly selected plants from each block.

\section{Statistical analysis}

The percentage of plants with B. bassiana, plant height, yield, insects and tunnel length per plant were arcsine percent square root transformed to normalize the data and the mean \pm SE of each parameter was back-transformed (Gomez and Gomez, 1984). The statistical significance of the difference between $B$. bassiana treated and control plants in the measured parameters was estimated through two-way ANOVA. Statistical analysis was done using Statistica software package (Statistica 6, 1995).

\section{Results}

First season experiment

Evaluation for endophytic presence of B. bassiana in sorghum

Stem culture. B. bassiana was detected in the stem cultures of treated plants but not in control plants. B. bassiana was found in

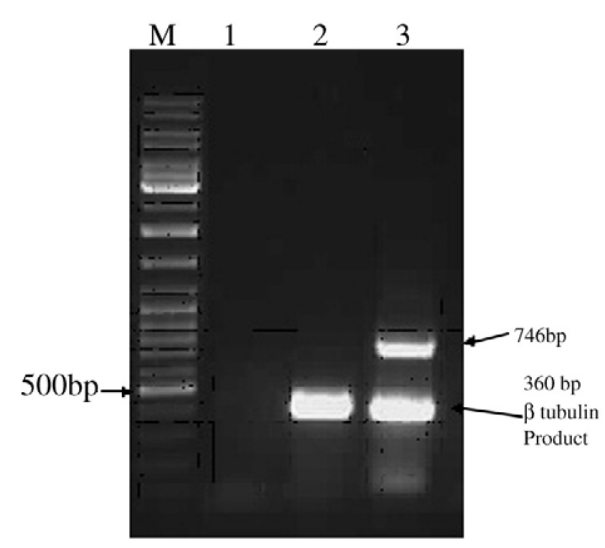

Fig. 1. PCR products amplified using primers specific for a conserved region of the fungal $\beta$ tubulin gene (Glass and Donaldson, 1995) from DNA of 1: sorghum, 2: Beauveria bassiana, 3: sorghum treated with $B$. bassiana. 

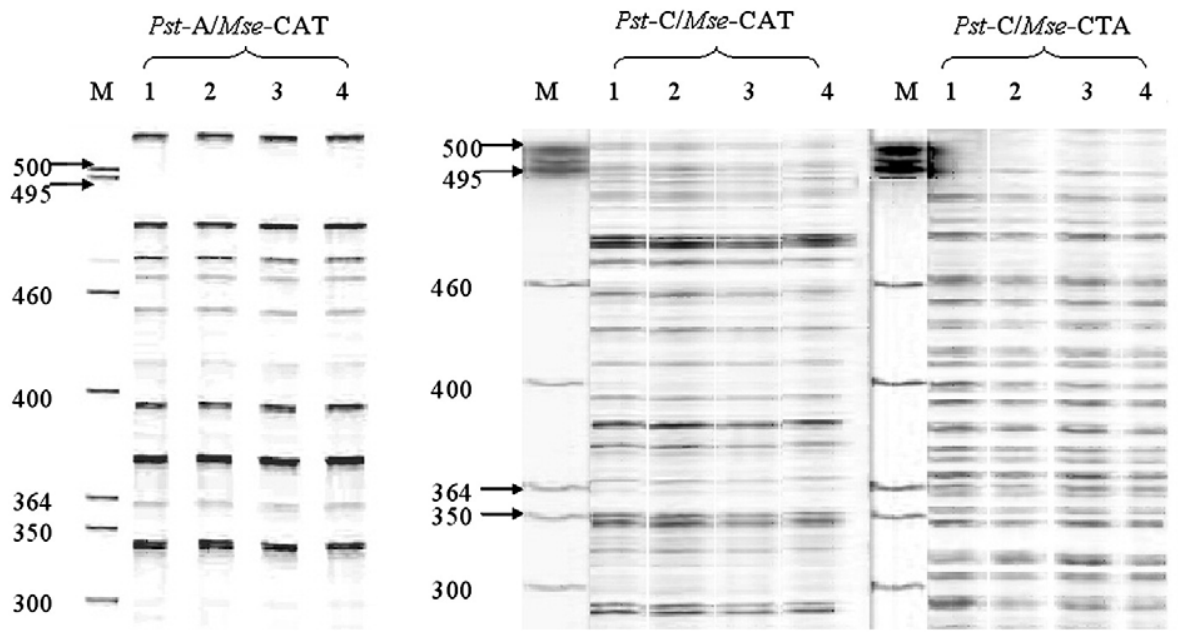

Fig. 2. AFLP fingerprints with three different primer combinations of Beauveria bassiana isolate ITCC 4688 used for treatment of sorghum (1) and B. bassiana isolates (2, 3, 4) retrieved from stem cultures of $B$. bassiana treated sorghum. M - DNA size marker.

stem pieces collected from all heights of the plant (Table 1). Fusarium and Aspergillus spp. were also observed in stem cultures.

The proportion of stems exhibiting $B$. bassiana colonization was significantly different among samples collected from different plant heights in both treatment types at both 30 and 60 days post treatment (Table 1 ). The stem pieces collected at medium height $(18,25 \mathrm{~cm}$ ) had more $B$. bassiana (Table 1). Endophytic establishment was significantly higher in samples collected 60 days after treatment than those collected 30 days after treatment (Table 1). Significantly higher colonization by $B$. bassiana was observed in plants treated with aqueous conidial spray than with conidiated fungal culture on rice (Table 1 ).

PCR amplification using primers specific for fungal $\beta$ tubulin gene. $\quad$ PCR amplified a 360 bp product in B. bassiana and in all six B. bassiana treated sorghum plants but not in untreated sorghum (Fig. 1). The PCR amplicons from the two sources, B. bassiana and B. bassiana treated sorghum, were identical to each other in sequence. In the $B$. bassiana treated sorghum, an additional band of 746 bp was also observed (Fig. 1). The sequences of both the PCR products were deposited in GenBank with the accession numbers DQ784576 and DQ871250. The 360 bp sequence showed $92 \%$ similarity with the $\beta$ tubulin-like (TUB2) gene of B. bassiana strain ARSEF 1640 with an $e$ value of $4 \mathrm{e}^{-59}$. The $746 \mathrm{bp}$ sequence from $B$. bassiana treated sorghum plants matched an 18 bp region in the Cytochrome P 450 gene of $M$. roridum. Because the sorghum plants in the $B$. bassiana treated plot showed brown spot symptoms caused by M. roridum, the 746 bp sequence is inferred to be from the $M$. roridum naturally infecting the sorghum plants.

AFLP fingerprints. AFLP fingerprints of all the three B. bassiana isolates were identical to the B. bassiana isolate ITCC 4688 with all the three primer combinations used (Fig. 2). Therefore, the B. bassiana found endophytically in sorghum is the one added through artificial inoculation and not a naturally associated strain.

\section{Assessment of growth and yield in B. bassiana treated sorghum}

No adverse effect on growth (as measured from plant height) or yield was observed in $B$. bassiana treated plants when compared with the controls (Table 2). All plants had three tillers each. Thus, the relationship of $B$. bassiana with sorghum can be inferred as one of an endophyte and not a pathogen.

\section{Second season experiment}

Assessment of effect of artificially infested C. partellus larvae on $B$. bassiana treated sorghum plants

The $B$. bassiana treated plants artificially infested with larvae of stem borer (C. partellus) had significantly fewer larvae than the controls (not treated with $B$. bassiana) 20 days post infestation (Table 3). About $40 \%(40.06 \pm 1.6)$ of the control plants that were artificially infested with $C$. partellus larvae dried up with dead hearts. In the surviving control plants, stem tunneling due to larval activity was significantly more than in B. bassiana treated sorghum (Table 3). Among the surviving control plants, about 36\% $(35.8 \pm 1.9)$ produced a panicle but plant height and grain yield were significantly reduced (Table 3 ).

Significant interactions were observed between the main factors: endophytic establishment $\times$ plant height $\left(F_{29,58}=235.21, P<0.05\right)$, resistance against $C$. partellus infestation $\times$ plant height $\left(F_{11,22}=489.12\right.$, $P<0.05)$, C. partellus infestation $\times$ tunneling length $\left(F_{5,10}=89.28\right.$, $P<0.05)$ and plant height $\times$ yield $\left(F_{10,20}=854.22, P<0.05\right)$.

Assessment of growth and yield in B. bassiana treated sorghum

In the second assessment of the effect of endophytic $B$. bassiana on growth and yield, the control plants not treated with B. bassiana

Table 2

Comparison of growth and yield of Beauveria bassiana treated and control (not treated) sorghum plants.

\begin{tabular}{|c|c|c|c|c|c|c|c|c|}
\hline & \multicolumn{4}{|c|}{ Aqueous conidial spray } & \multicolumn{4}{|c|}{ Conidiated fungal culture on rice } \\
\hline & \multicolumn{3}{|c|}{$\overline{\text { Plant height }(\mathrm{cm})^{\mathrm{a}}}$} & \multirow[t]{2}{*}{ Yield $(\mathrm{kg})^{\mathrm{a}}$} & \multicolumn{3}{|c|}{$\overline{\text { Plant height }(\mathrm{cm})^{\mathrm{a}}}$} & \multirow[t]{2}{*}{ Yield $(\mathrm{kg})^{\mathrm{a}}$} \\
\hline & 30 days & 60 days & 90 days & & 30 days & 60 days & 90 days & \\
\hline Treated & $53.6 \pm 0.7$ & $127.4 \pm 1.6$ & $203.6 \pm 7.3$ & $4.20 \pm 0.05$ & $60.8 \pm 1$ & $135 \pm 1.0$ & $203 \pm 2.7$ & $4.17 \pm 0.5$ \\
\hline Control & $53.6 \pm 0.8$ & $130.9 \pm 1.4$ & $208.3 \pm 4.3$ & $4.12 \pm 0.07$ & $60.5 \pm 1$ & $137 \pm 1.2$ & $207 \pm 2.1$ & $4.30 \pm 0.18$ \\
\hline ANOVA (treated $v s$ control) ${ }^{\mathrm{b}}$ & $\begin{array}{l}F_{1,2}=0.012 \\
P=0.92\end{array}$ & $F_{1,2}=7.7$ & $F_{1,2}=16.55$ & $F_{1,2}=5.16$ & $F_{1,2}=0.22$ & $F_{1,2}=2.46$ & $F_{1,2}=9.54$ & $F_{1,2}=0.41$ \\
\hline
\end{tabular}

\footnotetext{
${ }^{a}$ Values represent mean $\pm \mathrm{SE}$ of three replicate blocks with measurements of 20 plants from each.
}

b $P$ value in all comparisons is insignificant. 
Table 3

Comparison of effect of artificial infestation with larvae of stem borer in B. bassiana pretreated and control sorghum plants.

\begin{tabular}{|c|c|c|c|c|c|c|c|}
\hline \multirow[t]{2}{*}{ S. No. } & \multirow[t]{2}{*}{ Treatment type } & \multicolumn{3}{|c|}{ Plant height $(\mathrm{cm})^{\mathrm{a}}$} & \multirow{2}{*}{$\begin{array}{l}\text { Mean no. of } \\
\text { insects/plant }^{\mathrm{a}}\end{array}$} & \multirow{2}{*}{$\begin{array}{l}\text { Mean tunnel } \\
\text { length }(\mathrm{cm}) / \text { plant }^{\mathrm{a}}\end{array}$} & \multirow[t]{2}{*}{ Yield $(\mathrm{kg})^{\mathrm{a}}$} \\
\hline & & 30 days $^{\mathrm{b}}$ & 60th day & 90th day & & & \\
\hline 1 & Aqueous conidial (B. bassiana) spray and C. partellus infested & $18.63 \pm 0.43$ & $89.7 \pm 2.13$ & $98.7 \pm 2.5$ & $0.55 \pm 0.21$ & $4.06 \pm 0.64$ & $4.49 \pm 0.18$ \\
\hline 2 & Conidiated B. bassiana culture on rice and C. partellus infested & $16.86 \pm 0.62$ & $91.9 \pm 2.39$ & $97.9 \pm 2.13$ & $0.65 \pm 0.18$ & $4.51 \pm 0.98$ & $4.41 \pm 0.11$ \\
\hline 3 & Control - no B. bassiana treatment and C. partellus infested & $17.13 \pm 0.66$ & $39.5 \pm 1.14$ & $44.3 \pm 1.78$ & $3.25 \pm 0.72$ & $24.29 \pm 1.1$ & $2.84 \pm 0.1$ \\
\hline 4 & ANOVA treated $v s$ control & $F_{2,4}=6.09$ & $F_{2,4}=434^{c}$ & $F_{2,4}=273.6^{\mathrm{c}}$ & $F_{2,4}=2514.1^{\mathrm{c}}$ & $F_{2,4}=841.31^{c}$ & $F_{2,4}=44.14^{\mathrm{c}}$ \\
\hline 5 & Aqueous conidial (B. bassiana) spray & $18.38 \pm 0.36$ & $99.2 \pm 4.11$ & $119.5 \pm 4.14$ & - & - & $4.72 \pm 0.13$ \\
\hline 6 & Conidiated $B$. bassiana culture on rice & $18.31 \pm 0.72$ & $95.2 \pm 1.88$ & $103.9 \pm 2.2$ & - & - & $4.75 \pm 0.06$ \\
\hline 7 & Control - no B. bassiana treatment & $17.3 \pm 0.67$ & $63.5 \pm 1.18$ & $82 \pm 1.9$ & - & - & $3.55 \pm 0.15$ \\
\hline 8 & ANOVA treated $v s$ control & $F_{2,4}=2.58$ & $F_{2,4}=147^{c}$ & $F_{2,4}=855.1^{\mathrm{c}}$ & - & - & $F_{2,4}=39.3^{\mathrm{c}}$ \\
\hline 9 & ANOVA (all treatments vs both controls) & $F_{5,10}=121.22$ & $F_{5,10}=355^{c}$ & $F_{5,10}=456.3^{c}$ & - & - & $F_{5,10}=98.06^{c}$ \\
\hline 10 & ANOVA (control S. No. 3 vs control S. No. 7) & $F_{1,2}=11.29$ & $F_{1,2}=31^{\mathrm{c}}$ & $F_{1,2}=191^{\mathrm{c}}$ & - & - & $F_{1,2}=89.22^{\mathrm{c}}$ \\
\hline
\end{tabular}

a Values represent mean $\pm \mathrm{SE}$ of three replicate blocks with measurements of 20 plants from each.

b At the time of treatment.

c $P$ value is significant.

showed significantly less growth and yield compared to the treated plants (Table 3, S. No. 8). The natural aphid infestation of sorghum plants at the time of treatment with B. bassiana was completely wiped out within 5 days of treatment with $B$. bassiana while it persisted for 30 days in the control plants not treated with $B$. bassiana. At later stages, the control plants also showed natural, mild infestation of Helicoverpa armigera and Mythimna seperata. These insect pests were not noticed on B. bassiana treated plants. The effect of the natural attack of these pests in control plants was reflected in their growth. Treatment with $B$. bassiana thus bestowed protection against the naturally infesting insect pests - aphids, $H$. armigera and $M$. seperata.

There were significant differences in growth and yield between the two controls not treated with B. bassiana - sorghum artificially infested with C. partellus (Table 3, S. No. 3) and not infested (Table 3, S. No. 7). Artificial infestation with C. partellus resulted in significantly decreased plant height and yield compared to the uninfested plants (Table 3, S. No. 10).

\section{Discussion}

As reported in earlier studies with different plant species, treatment of sorghum with $B$. bassiana did result in its endophytic establishment. This is the second cereal crop (after maize) found to harbor B. bassiana endophytically when treated. B. bassiana was found in samples collected from different heights of the plant indicating its establishment throughout the plant. B. bassiana is spread throughout the corn stems by passive movement through xylem vessels (Wagner and Lewis, 2000).

In sorghum, treatment with aqueous conidial spray was more effective than treatment with conidiated fungal culture on rice in facilitating endophytic establishment. In corn, no difference in the treatments was observed (Lewis et al., 2001).

The sorghum plants examined for endophytic presence of $B$. bassiana through PCR amplification with fungal specific $\beta$ tubulin gene primers gave a positive result. Beta tubulin sequences could be amplified from the DNA isolated from $B$. bassiana treated sorghum. Furthermore, the PCR products from B. bassiana and sorghum treated $B$. bassiana were identical in sequence. Using a similar molecular approach, B. bassiana could not be detected in B. bassiana treated tomato seedlings, though it was endophytically present (Ownley et al., 2004). White et al. (1990) attribute the failure in their approach to use of universal rather than fungal specific primers.

Corn is reported to harbor B. bassiana naturally as an endophyte (Bing and Lewis, 1991). In our study, the AFLP fingerprints of $B$. bassiana used for treatment of sorghum and the B. bassiana cultures retrieved through stem culture from B. bassiana treated sorghum plants were identical. It is therefore concluded that the $B$. bassiana isolate found endophytically in sorghum is the one established through artificial inoculation and not a naturally associated strain.

In the experiment done in the first season, sorghum plants treated with $B$. bassiana showed brown spot disease caused by $M$. roridum while the controls not treated with $B$. bassiana showed no phytopathogenic infection of $M$. roridum. However, tomato seeds treated with $B$. bassiana had resistance to the phytopathogenic fungus, Rhizoctonia solani, which causes seedling wilt (Ownley et al., 2004).

B. bassiana treatment of sorghum not only resulted in its endophytic establishment but also provided effective protection when challenged with stem borer infestation, as has been reported in corn (Bing and Lewis, 1992) and banana (Akello et al., 2008). The natural aphid infestation prevailing on sorghum plants at the time of treatment with $B$. bassiana was also decimated. Natural infestation by other insect pests like army worm and Helicoverpa armigera was spotted on control sorghum plants but not on B. bassiana treated plants. All these insects are among the long host list of $B$. bassiana.

Thus, treatment of sorghum at the seedling stage with the entomopathogenic fungus $B$. bassiana can be used as an effective method for establishing the fungus endophytically to protect from the plant intruding stem borer as well as other insect pests.

\section{Acknowledgments}

We thank the Andhra Pradesh Netherlands Biotechnology Unit, Institute of Public Enterprise, Osmania University Campus, Hyderabad, India for financial support (project number: BTU P-76). We thank DST (New Delhi, India) and DAAD (Germany) for financial support for collaboration under DST-DAAD PPP 03 programme INT/ DAAD/P-89/2003. Narasimha Reddy P thanks APCOST, Hyderabad for a Young Scientist Fellowship.

\section{References}

Akello, J., Dubois, T., Coyne, D., Kyamanywa, S., 2008. Endophytic Beauveria bassiana in banana (Musa spp.) reduces banana weevil (Cosmopolites sordidus) fitness and damage. Crop Prot. 27, 1437-1441.

Altschul, S.F., Gish, W., Miller, W., Myers, E.W., Lipman, D.J., 1990. Basic local alignment search tool. J. Mol. Biol. 215, 403-410.

Arnold, A.E., Lewis, L.C., 2005. Ecology and evolution of fungal endophytes and their roles against insects. In: Vega, F.E., Blackwell, M. (Eds.), Insect-Fungal Associations: Ecology and Evolution. New York, Oxford University Press, pp. 74-96.

Bills, G.F., Polishook, J.D., 1991. Microfungi from Carpinus caroliniana. Can. J. Bot. 69, 1477-1482.

Bing, L.A., Lewis, L.C., 1991. Suppression of Ostrinia nubilalis by endophytic Beauveria bassiana. Environ. Entomol. 20, 1207-1211.

Bing, L.A., Lewis, L.C., 1992. Endophytic Beauveria bassiana (Balsamo) Vuillemin in corn, the influence of the plant growth stage and Ostrinia nubilalis (Hübner). Biocontrol Sci. Tech. 2, 39-47.

Chase, A.R., Osborne, L.S., Ferguson, V.M., 1986. Selective isolation of the entomopathogenic fungi Beauveria bassiana and Metarhizium anisopliae from an artificial potting medium. Fla. Entomol. 69, 285-292. 
Ganley, R.J., Newcombe, G., 2006. Fungal endophytes in seeds and needles of Pinus monticola. Mycol. Res. 110, 318-327.

Gethi, M., Mutind, A.C., Diallo, A., 2001. Stem borers in maize: a natural stress and progress towards host plant resistance. Proceedings of the 7th Eastern and Southern Africa Regional Maize Conference; Feb 11-15; Nairobi. Kenya, pp. 45-48. 2001.

Glass, N.L., Donaldson, G.C., 1995. Development of primer sets designed for use with the PCR to amplify conserved genes from filamentous ascomycetes. Appl. Environ. Microbiol. 61, 323-330.

Gomez, A.K., Gomez, A.A., 1984. Statistical Procedures for Agricultural Research. John Wiley and son's Inc., Singapore, pp. 643-645.

Gomez Vidal, S., Lopez Llorca, L.V., Jansson, H.B., Salinas, J., 2006. Endophytic colonization of date palm (Phoenix dactylifera L.) leaves by entomopathogenic fungi. Micron 37, 624-632.

Inglis, G.D., Goettel, M.S., Johnson, D.L., 1995. Influence of ultraviolet light protectants of the entomopathogenic fungus, Beauveria bassiana. Biol. Control 5, 581-590.

Jenkins, N.E., Heviefo, G., Langewald, J., Lomer, C.J., 1998. Development of mass production technology for aerial conidia for use as mycopesticides. Biocontrol News Infor. 19, 21-31.

Jones, K.D., 1994. Aspects of the biology and biological control of the European corn borer in North Carolina. PhD thesis. North Carolina State University, Raleigh.

Leckie, B.M., 2002, Effects of Beauveria bassiana mycelia and metabolites incorporated into synthetic diet and fed to larval Helicoverpa zea, and detection of endophytic Beauveria bassiana in tomato plants using PCR and ITS (MS thesis). The University of Tennessee, Knoxville.

Lewis, L.C., Bruck, D.J., Gunnarson, R.D., Bidne, K.G., 2001. Assessment of plant pathogenicity of endophytic Beauveria bassiana in Bt. transgenic and non-transgenic corn. Crop Sci. 41, 1395-1400.

Luginbuhl, M., Muller, E., 1980. Endophtische Pilze in den oberirdischen Organen von 4 gemeinsam an gleichen Standorten wachsenden Pflanzen (Buxus, Hedera Ilex, Ruscus). Sydowia 33, 185-209.

Maniania, N.K., 1993. Evaluation of three formulations of Beauveria bassiana for control of the stem borer Chilo partellus. J. Appl. Entomol. 115, 266-272.
Ownley, B.H., Pereira, R.M., Klingeman, W.E. Quigley, N.B., Leckie, B.M., 2004. Beauveria bassiana, a dual purpose biocontrol organism, with activity against insect pests and plant pathogens. In: Lartey, R.T., Caesar, A.J. (Eds.), Emerging Concepts in Plant Health Management. Research Signpost, Trivandrum, Kerala, India, pp. 255-269.

Posada, F., Vega, F.E., 2006. Inoculation and colonization of coffee seedlings (Coffea arabica L.) with the fungal entomopathogen Beauveria bassiana (Ascomycota: Hypocreales). Mycoscience 47, 284-289.

Posada, F., Aime, M.C., Peterson, S.W., Rehner, S.A., Vega, F.E., 2007. Inoculation of coffee plants with the fungal entomopathogen Beauveria bassiana (Ascomycota: Hypocreales). Mycol. Res. 111, 748-757.

Posada, F.J., Vega, F.E., 2005. Establishment of the fungal entomopathogen Beauveria bassiana (Ascomycota: Hypocreales) as an endophyte in cocoa seedlings (Theobroma cacao). Mycologia 97, 1208-1213.

Quesada-Moraga, E Landa, B.B. Muñoz-Ledesma, J. Jiménez-Diáz, R.M., SantiagoÁlvarez Morga, C., 2006. Endophytic colonisation of opium poppy, Papaver somniferum, by an entomopathogenic Beauveria bassiana strain. Mycopathologia $161,323-329$.

STATISTICA 6 for Windows, 1995. StatSoft, Inc., Tulsa, OK.

Uma Devi, K., Padmavathi, J., Sharma, H.C., Seetharama, N., 2001. Laboratory evaluation of the virulence of Beauveria bassiana isolates to the sorghum shoot borer Chilo partellus and their characterization by RAPD-PCR. World J. Microbiol. Biotech. 17, 131-137.

Uma Devi, K, Reineke, A, Nageswara Rao Reddy, N, Uma Maheswara Rao, C. Padmavathi, J., 2006. Genetic diversity, reproductive biology, and speciation in the entomopathogenic fungus Beauveria bassiana (Balsamo) Vuillemin. Genome 49, 495-504.

Wagner, B.L., Lewis, L.C., 2000. Colonization of corn, Zea mays, by the entomopathogenic fungus Beauveria bassiana. Appl. Environ. Microbiol. 66, 3468-3473.

White, T.J., Bruns, T., Lee, S., Taylor, J.W., 1990. Amplification and direct sequencing of fungal ribosomal RNA genes for phylogenetics. In: Innis, M.A., Gelfand, D.H., Sninsky, J.J., White, T.J. (Eds.), PCR Protocols: A Guide to Methods and Applications. Academic Press Inc., New York, pp. 315-322. 